Jurnal Cakrawala: Studi Manajemen Pendidikan Islam dan Studi Sosial P-

ISSN: 2580-9385, E-ISSN: 2581-0197

Vol.4 No.2 Th 2020

http://ejournal.iainu-kebumen.ac.id/index.php/cka/index

\title{
PENGEMBANGAN SDM DALAM PENDIDIKAN ISLAM
}

\author{
Benny Kurniawan \\ Institut Agama Islam Nahdlatul Ulama Kebumen \\ Email: 63nny.k@gmail.com
}

\begin{abstract}
ABSTRAK
Investasi pengembangan SDM merupakan program jangka panjang yang di dalamnya terdapat program jangka menengahyang harus sedini mungkin diformulasikan perencanaanya dan diimplementasikan. Investasi ini harus menunjang perkembangan ekonomi dengan visi membangun suatu masyarakat madani yang makmur dan berkeadilan. Dalam hal ini ada tiga hal yang perlu dilakukan yaitu sumber daya sejarah dan budaya, kualitas sumber daya manusia, pemberdayaan rakyat.Madrasah dalam tujuannya berupaya mengintegrasikan ilmu agama dan umum. Menyeimbangkan keduanya untuk menggapai kebahagiaan dunia dan akhirat. Ada beberapa aspek yang perlu dikembangkan dalam lingkup lembaga pendidikan Islam pada umumnya, dan Madrasah pada khususnya untuk menumbuhkan kualitas SDM yang berwawasan global paling tidak harus asanya pengelolaan yang baik dari aspek pendidikan (pedagogis), aspek Moral-Spiritual, aspek sosio-kultural, aspek Sistem pendidikan, aspek sarana dan prasarana.
\end{abstract}

Kata kunci: Pengembangan SDM, pendidikan Islam

\section{A. Pendahuluan}

Sumber daya manusia (SDM) merupakan salah satu faktor penting dalam pembangunan. Secara makro, faktor-faktor masukan pembangunan, seperti sumber daya alam, material dan finansial tidak akan memberi manfaat secara optimal untuk perbaikan kesejahteraan rakyat bila tidak didukung oleh memadainya ketersediaan faktor SDM, baik secara kualitas maupun kuantitas. Pelajaran yang dapat dipetik dari berbagai negara maju adalah, bahwa kemajuan yang dicapai oleh bangsa-bangsa di negara-negara tersebut didukung oleh SDM yang berkualitas. Jepang, misalnya, sebagai negara pendatang baru (late comer) dalam kemajuan industri dan ekonomi memulai upaya mengejar ketertinggalannya dari negara-negara yang telah lebih dahulu mencapai kemajuan ekonomi dan industri (fore runners) seperti Jerman, perancis dan Amerika dengan cara memacu pengembangan SDM.

Dalam konteks mikro, SDM juga diperlukan oleh setiap institusi kemasyarakatan dan organisasi. Berbagai institusi kemasyarakatan, seperti institusi keluarga, institusi ekonomi, dan institusi keagamaan, SDM merupakan unsur penting dalam pembinaan dan 
pengembangannya. Demikian pula dalam organisasi, SDM berperan sangat penting dalam pengembangannya, terutama bila diinginkan pencapaian tujuan yang optimal. Bila tujuan akhir setiap kegiatan pembangunan, baik dalam konteks makro maupun mikro, adalah peningkatan taraf hidup, maka optimalisasi pencapaian tujuan itu adalah terpenuhinya kebutuhan dasar manusia secara optimal. Berdasarkan konsep di atas, dukungan SDM yang berkualitas sangat menentukan keoptimalan keberhasilan pencapaian tujuan itu.

Kualitas SDM ditentukan oleh berbagai faktor yang saling berkaitan, diantaranya kesehatan dan kemampuan. Faktor kemampuan sebagai salah satu faktor penentu kualitas SDM bisa dikembangkan di antaranya melalui pendidikan. Jadi, pendidikan merupakan suatu upaya dalam proses pengembangan SDM.

\section{B. Pengertian dan Hakikat SDM}

Emil Salim menyatakan bahwa yang dimaksud dengan SDM adalah kekuatan daya pikir atau daya cipta manusia yang tersimpan dan tidak dapat diketahui dengan pasti kapasitasnya. SDM dapat diartikan sebagai nilai dari perilaku seseorang dalam mempertanggungjawabkan semua perbuatannya, baik dalam kehidupan pribadi maupun dalam kehidupan berkeluarga, bermasyarakat dan berbangsa. Dengan demikian kualitas SDM ditentukan oleh sikap mental manusia. Sedangkan menurut Hadawi Nawawi Sumber daya manusia (SDM) adalah daya yang bersumber dari manusia, yang berbentuk tenaga atau kekuatan (energi atau power). Sumber daya manusia mempunyai dua ciri, yaitu : (1) Ciri-ciri pribadi berupa pengetahuan, perasaan dan keterampilan. (2) Ciri-ciri interpersonal yaitu hubungan antar manusia dengan lingkungannya. ${ }^{1}$

T. Zahara Djafar menyatakan bahwa bila kualitas SDM tinggi, yaitu menguasai ilmu dan teknologi dan mempunyai rasa tanggung jawab terhadap kehidupan manusia dan makhluk hidup lainnya dan merasa bahwa manusia mempunyai hubungan fungsional dengan sistem sosial, nampaknya pembangunan dapat terlaksana dengan baik seperti yang telah negara-negara maju, dalam pembangunan bangsa dan telah berorientasi ke masa depan. Tidak jarang di antara negara-negara maju yang telah berhasil meningkatkan kesejahteraan bangsanya adalah bangsa yang pada mulanya miskin namun memiliki SDM yang berkualitas.

Dalam Islam sosok manusia terdiri dua potensi yang harus dibangun, yaitu lahiriah sebagai tubuh itu sendiri dan ruhaniyah sebagai pengendali tubuh. Pembangunan

\footnotetext{
${ }^{1}$ Simanjuntak, P., Pengantar Ekonomi Sumber Daya Manusia,(Jakarta: Lembaga Penerbit Fakultas Ekonomi, Universitas Indonesia, 1985), hlm. 45.
} 
manusia dalam Islam tentunya harus memperhatikan kedua potensi ini. Jika dilihat dari tujuan pembangunan manusia Indonesia yaitu menjadikan manusia seutuhnya, maka tujuan tersebut harus memperhatikan kedua potensi yang ada pada manusia. Namun upaya kearah penyeimbangan pembangunan kedua potensi tersebut selama 32 tahun masa orde baru hanya dalam bentuk konsep saja tanpa upaya aplikasi yang sebenarnya. Telah dimaklumi bahwa pendidikan Islam memandang tinggi masalah SDM ini khususnya yang berkaitan dengan akhlak (sikap, pribadi, etika dan moral).

Tantangan manusia pada millennium ke-3 ini akan terfokus pada berbagai aspek kompleks. Khusus dibidang pendidikan Aly dan Munzier menyebutkan bahwa tantangan pendidikan Islam terbagi atas 2, yaitu tantangandariluar, yaitu berupa pertentangan dengan kebudayaan Barat abad ke-20 dan dari dalam Islam itu sendiri, berupa kejumudan produktivitas keislaman. $^{2}$

Abdul Rachman Shaleh menyatakan bahwa untuk menjawab tantangan dan menghadapi tuntutan pembangunan pada era globalisasi diisyaratkan dan diperlukan kesiapan dan lahirnya masyarakat modern Indonesia. Aspek yang spektakuler dalam masyarakat modern adalah penggantian teknik produksi dari cara tradisional ke cara modern yang ditampung dalam pengertian revolusi industri. Secara keliru sering dikira bahwa modernisasi hanyalah aspek industri dan teknologi saja. Padahal secara umum dapat dikatakan bahwa modernisasi masyarakat adalah penerapan pengetahuan ilmiah yang ada kepada semua aktivitas dan semua aspek hidup masyarakat.

Dalam upaya pembangunan masyarakat, tidak ada suatu masyarakat yang bisa ditiru begitu saja, tanpa nilai atau bebas nilai. Hal ini telah terlihat dengan peniruan dan pengambilan pola kehidupan sosialis, materialistis yang ditiru masyarakat Indonesia. Untuk itu perlu pembangunan di bidang agama. A. R. Saleh menyatakan bahwa pembangunan di bidang agama diarahkan agar semakin tertata kehidupan beragama yang harmonis, semarak dan mendalam, serta ditujukan pada peningkatan kualitas keimanan dan ketaqwaan terhadap Tuhan YME, terciptanya kemantapan kerukunan beragama, bermasyarakat dan berkualitas dlam meningkatkan kesadaran dan peran serta akan tanggung jawab terhadap perkembangan akhlak serta untuk secara bersama-sama memperkukuh kesadaran spiritual, moral dan etik bangsa dalam pelaksanaan pembangunan nasional, peningkatan pelayanan, sarana dan prasarana kehidupan beragama.

\footnotetext{
${ }^{2}$ Aly, H. N. dan Munzier, H., Watak Pendidikan Islam (Jakarta : Friska Agung Insani, 2001). hlm. 227.
} 
Kualitas SDM menyangkut banyak aspek, yaitu aspek sikap mental, perilaku, aspek kemampuan, aspek intelegensi, aspek agama, aspek hukum, aspek kesehatan dan sebagainya. ${ }^{3}$ Kesemua aspek ini merupakan dua potensi yang masing-masing dimiliki oleh tiap individu, yaitu jasmaniah dan ruhaniah. Tidak dapat dipungkiri bahwa aspek jasmaniah selalu ditentukan oleh ruhaniah yang bertindak sebagai pendorong dari dalam diri manusia.

Masyarakat yang sedang membangun adalah masyarakat yang sedang berubah dan terkadang perubahan tersebut sangat mendasar dan mengejutkan. Masyarakat yang sedang dibangun berarti masyarakat terbuka, yang memberi peluang untuk masuknya modal, ilmu dan teknologi serta nilai dan moral asing yang terkadang tidak sesuai dengan kepribadian bangsa. Untuk itu peran agama diharapkan dapat berfungsi sebagai pengarah dan pengamanan pembangunan nasional. Dalam masyarakat yang sedang berubah ini terdapat objek paling rawan yaitu generasi muda, untuk itu prioritas perhatian pada generasi muda ini perlu ditingkatkan demi keberhasilan pembangunan.

Dalam mengembangkan SDMnya, seseorang yang menjalankan karyanya harus benar-benar serius dan mampu menjaga konsistensinya agar nantiya mendapatkan kegembiraan dan kepuasan. Dale Carnagie menunjukan bagaimana memetik kepuasan kerja sebesar-besarnya sepanjang waktu, menggali dan menggunakan bakat dan kemampuan yang selama ini banyak yang tidak menyadari. Ia menyarankan para pekerja untuk :

1. Selalu mendasarkan pekerjaan pada perolehan kedamain dan kebahagiaan.

2. Menghadapi orang dengan bijak dan adil.

3. Mencari partner atau kawan bukan mencari lawan.

4. Mengubah orang tanpa menimbulkan perlawanan atau sakit hati. ${ }^{4}$

\section{Urgensi Pengembangan SDM}

Sumber daya manusia (SDM) merupakan aset utama suatu organisasi, baik organisasi bisnis maupun organisasi nirlaba. Masa depan dan kelestarian suatu organisasi tergantung pada pengetahuan, keterampilan dan kompetensi SDM, serta sinergi antara SDM sebagai penggerak organisasi dan pengelolaan yang efektif sumber daya lainnya yang ada dalam organisasi tersebut. SDM merupakan aset yang paling pelik untuk

\footnotetext{
${ }^{3}$ Djaafar, T. Z. Pendidikan Non Formal Dan Peningkatan Sumber Daya Manusia Dalam Pembangunan. Padang, (Padang : FIP UNP, 2001). hlm. 1-2.

${ }^{4}$ Dale Carnagie, Petunjuk Menikmati Hidup dan Pekerjaan Anda (Jakarta: Gramedia, 2004), hlm cover akhir.
} 
dikelola karena keunikan individu, perbedaan kompetensi, kualifikasi, keahlian serta latar belakang SDM yang menjadi bagian dari suatu organisasi. Perhatian yang sungguhsungguh terhadap SDM dalam suatu organisasi makin meningkat karena produktivitas suatu organisasi banyak ditentukan oleh kinerja SDMnya. ${ }^{5}$

Menurut Gilley dan Eggland, pengembangan SDM mempunyai tiga misi yaitu, pertama, untuk memungkinkan terjadinya proses perkembangan individu, terutama terfokus pada peningkatan kinerja yang terkait dengan pekerjaan yang ditangani. Kedua, menyiapkan pengembangan karir yang terfokus pada peningkatan kinerja yang terkait dengan penugasan dalam jabatan di masa yang akan datang. Ketiga, menyediakan pengembangan organisasi yang menghasilkan penggunaan potensi manusia dan kinerjanya yang meningkat. Jadi, pada intinya pengembangan SDM terkait dengan pemanfaatannya dalam pembangunan sebagai suatu upaya melakukan perubahan ke arah perbaikan yang bertujuan untuk memperbaiki taraf hidup, meningkatkan kesejahteraan dan meningkatkan kualitas SDM. Makna dari konsep ini adalah, bahwa perubahan yang diupayakan melalui pembangunan bukan hanya menjangkau segi-segi material saja, tetapi juga menjangkau seluruh aspek kehidupan. ${ }^{6}$ Diantara manfaat pengembangan SDM yaitu:

a. Dengan perencanaan, rekrutmen, dan seleksi yang baik dapat memperoleh tenaga kerja vang produktif.

b. Fungsi pengembangan staf membantu individu, kelompok, dan organisasi rnenjadi lebih eiektif.

c. Program insentif yang besar terbukti dapat membawa dampak positif pada organisasi.

d. Lingkungan kerja yang aman dan sehat cenderung meningkatkan prduktivitas

e. Hubungan pekerja-manajemen yang efekif membawa hasiI yang lebih baik bagi Organisasi. $^{7}$

Proses pembangunan memerlukan partisipasi seluruh lapisan masyarakat, agar segala yang dilaksanakan dan dihasilkan bisa mereka rasakan manfaatnya. Di samping itu, pembangunan tidak akan mencapai hasil optimal dan keberhasilannya tidak bisa dirasakan semua lapisan tanpa partisipasi aktif masyarakat, meskipun mendorong partisipasi masih menjadi tantangan pembangunan (Slamet, 1992). Proses pembangunan

\footnotetext{
${ }^{5}$ Yasnimar Ilyas dan Amin Zuhairi, "Pengembangan Sistem Penilaian Kinerja Sumber Daya Manusia Pada Institusi Pendidikan Tinggi Jarak Jauh”, Jurnal Pendidikan Terbuka dan Jarak Jauh, Vol. 5, No.1, Maret 2004, 1-18.

${ }^{6}$ Abdullah NS., “Pemberdayaan Budaya”,Mimbar Pendidikan, No. 3/XVII/ 1998, hlm. 28.

${ }^{7}$ Hartoyo, "Pengembangan Sumber Daya Manusia (SDM) Pendidikan", Pelatihan Peningkatan Kemampuan Tenaga Perencana Akademik Bagi Dosen STTA Yogyakarta. 1 Agustus 2008 Di P3AI UNY.
} 
adalah proses sosial dalam menjadikan SDM lebih kompetens untuk hidup dalam dunia yang terus berubah. Untuk ini perlu dilaksanakan program pengembangan SDM. Program pengembangan SDM pembangunan ini bukan hanya menjadi tanggung jawab pemerintah, tetapi oleh setiap orang yang menaruh perhatian yang sungguh-sungguh terhadap pembangunan dan peningkatan taraf hidup dan peningkatan kualitas SDM.

Untuk ini perlu dilaksanakan program pengembangan SDM. Program pengembangan SDM pembangunan ini bukan hanya menjadi tanggung jawab pemerintah, tetapi oleh setiap orang yang menaruh perhatian yang sungguh-sungguh terhadap pembangunan dan peningkatan taraf hidup dan peningkatan kualitas SDM. Dalam suatu artikel yang dimuat oleh majalah Psychology Today, Dormen and Adidin (1989), memaparkan sejumlah hasil studi tentang bagaimana orang mampu bertahan (survive) dalam situasi kehidupan yang penuh dengan persaingan. Faktor utama yang menyebabkan seseorang mampu bertahan dalam situasi kehidupan semacam itu adalah kemampuan menyesuaikan diri dengan tuntutan situasi yang dihadapi. Ini sangat penting, karena situasi yang dihadapi, apalagi situasi yang akan datang, penuh dengan perubahan yang seringkali tidak bisa diperkirakan dengan tepat. Untuk bisa bertahan dalam kehidupan yang cepat berubah diperlukan pola-pola prilaku yang sesuai dengan tuntutan situasi. Untuk itu, setiap anggota masyarakat seharusnya belajar untuk mengenali dan menguasai pola-pola prilaku seperti itu, agar mampu menyesuaikan diri sehingga bisa bertahan. Kecepatan perubahan dan keketatan persaingan merupakan kenyataan yang tidak bisa dihindari. Kenyataan ini muncul disebabkan oleh:

1. Perubahan dalam bidang ekonomi. Perubahan ini merupakan dampak langsung dari perubahan global dalam sistem perdagangan, seperti perdagangan bebas, AFTA dan NAFTA, yang dapat menyebabkan batas-batas antar negara menjadi semu.

2. Perubahan dalam bidang ilmu pengetahuan dan teknologi (IPTEK). Tingkat penguasaan IPTEK suatu bangsa akan menentukan kemajuan ekonomi bangsa itu. Agar mampu mempertahankan pertumbuhan ekonomi yang stabil, atau bahkan meningkatkannya, diperlukan pengusaan terhadap IPTEK.

3. Perubahan dalam bidang sosial-budaya. Globalisasi dalam kehidupan yang disebabkan oleh kemajuan dalam teknologi komunikasi menyebabkan terjadinya perubahan dalam bidang sosial dan budaya. Ini dikarenakan arus informasi yang tidak mengenal batas menimbulkan terjadinya adopsi budaya dari luar yang hampir tak terkendali. 
4. Tantangan yang diakibatkan oleh perubahan-perubahan itu menuntut kemampuan menyesuaikan diri dari setiap anggota masyarakat. Dalam konteks ini pegembangan SDM dimaksudkan untuk meningkatkan kemampuan menyesuaikan diri agar dalam situasi perubahan apapun yang terjadi setiap individu dapat memenuhi kebutuhan dasar hidupnya. Ini bisa dicapai apabila prosesnya selain diarahkan pada peningkatan derajat ketahan fisik (seperti kesehatan) juga kepada peningkatan derajat kompetensi yang memungkinkan mereka bisa survive dalam berbagai situasi dan kondisi yang selalu berubah itu. ${ }^{8}$

\section{Formulasi Pengembangan SDM}

Investasi pengembangan SDM merupakan program jangka panjang yang di dalamnya terdapat program jangka menengahyang harus sedini mungkin diformulasikan perencanaanya dan diimplementasikan. Investasi ini harus menunjang perkembangan ekonomi dengan visi membangun suatu masyarakat madani yang makmur dan berkeadilan. Dalam hal ini ada tiga hal yang perlu diperhatikan yaitu:

1. Sumber daya sejarah dan budaya

Ketahanan suatu masyarakat ditentukan oleh tiga unsur yakni sumber daya alam, sumber daya manusia yang berkualitas dan sumber daya kebudayaan dan kesejarahannya. Oleh karena itu suatu daerah perlu mengembangkan nilainilai kebudayaannya yang luhur sebagai modal untuk membangun daerahnya. Hanya anggota masyarakat yang berbudaya yaitu yang mempunyai kebangaan terhadap masyarakat dan budayanya, akan menjadi unsur-unsur SDM yang produktif dan kompetitif dalam era globalisasi. Manusia yang tidak berbudaya akan tenggelam karena tidak mempunyai identitas. Manusia yan tidak mempunyai identitas tidak merasa bangga akan keterkaitanya dengan masyarakatnya sehingga tidak diharapkan lagi menjadi manusia yang produktif bagi masyarakatnya.

2. Kualitas Sumber Daya Manusia

Investasi SDM yang diharapkan adalah anggota masyarakat yang mempunyai karakteristik sebagai berikut:

\footnotetext{
${ }^{8}$ Moh. Ali, "Pendidikan dan Perspektif" Mimbar Pendidikan, No. 3/XVIII/1999, hlm. 29.
} 
a. Manusia yang berwatak, yaitu manusia yang jujur, yang mempunyai sosial capital yaitu manusia yang dapat dipercaya, yang suka bekerja keras, jujur dan inovatif.

b. Seorang yang pintar atau intelegen. Seorang intelegen bukan hanya orang akademis tetapi kemampuan yang bermacam-macam yang harus dikembangkan oleh semua orang.

c. Enterpreneur (wiraswasta).Seseorang yang mempunyai kemampuan intrepreneur adalah sesorang yang inovatif yang tidak terkat oleh suatu yang telah tetap. Seseorang yang mempunyai tingkah laku intrepreneurship yang telah berkembang adalah seseorang yang dapat hidup di dalam berbagai situasi dan kondisi dan tidak mungkin menjadi seorang penganggur.

d. Watak yang kompetitif. Seorang yang mempunyai sifat kompetitif akan selalu tidak puas dengan apa yang telah dicapainya. Setiap saat dia mencari jalan untuk meningkatkan produktifitasnya, baik dari segi kuantitatif maupun dari segi kualitatif. Hanya oran yang kempetitif yang dapat survive didalam dunia yang penuh persaingan. Sikap kompetitif seperti ini sudah harus ditumbuhkan di dalam keluarga juga di dalam semua tingkat pendidikan formal.

3. Pemberdayaan rakyat

Pemberdayaan SDM yang lemah pada hakikatnya adalah memberdayakan rakyat banyak agar mereka dapat berdiri sendiri dan mau mengubah nasibnya sendiri. Hanya rakyat yang berdaya yang dapat mengatasi kesulitan yang dihadapina termasuk pengentasan kemiskinan. Rakyat yang berdaya adalah rakyat yang menguasai ilmu pengetahuan dan ketrampilan yang sesuai untuk mengolah SDA yang ada disekitarnya. Pusat-pusat pelatihan perlu didirikan dan dikordinasikan agar tidak mubazir. ${ }^{9}$

Suatu perumpamaan yang layak untuk menjadi teladan bagi SDM yang tidak berdaya adalah orang cerdik akan berusaha merubah kerugian menjadi keuntungan. Sedangkan orang bodoh akan membuat suatu musibah menjadi bertumpuk dan berlipat ganda. Ketika Rasulullah s.a.w. diusir dari Makkah, beliau memutuskan untuk menetap di Madinah dan kemudian berhasil membangunnya menjadi sebuah negara yang sangat akrab di telinga dan mata sejarah. Ahmad ibn Hanbal pernah dipenjara dan dihukum dera, tetapi karenanya pula ia kemudian menjadi imam salah satu madzhab. Ibnu Taimiyyah pernah di penjara, tetapi

${ }^{9}$ H.A.R. Tilaar, Membenahi Pendidikan nasional, (Jakarta : Rineka Cipta, 2002), hlm. 60-62. 
justru di penjara itulah ia banyak melahirkan karya. As-Sarakhsi pernah dikurung di dasar sumur selama bertahun-tahun, tetapi di tempat itulah ia berhasil mengarang buku sebanyak dua puluh jilid. Ketika Ibnul-Atsir dipecat dari jabatannya, ia berhasil menyelesaikan karya besarnya yang berjudul Jami'ul Ushul dan an-Nihayah, salah satu buku paling terkenal dalam hadits. Demikian halnya dengan Ibnul-Jawzy, ia pernah diasingkan dari Baghdad, dan karena itu ia menguasai qiraah $s a b^{\prime} a h$. Malik ibn ar-Raib adalah penderita suatu penyakit yang mematikan, namun ia mampu melahirkan syair-syair yang sangat indah dan tak kalah dengan karya-karya para penyair besar zaman Abbasiyah. Lalu, ketika semua anak Abi Dzuaib al-Hudzali mati meninggalkannya seorang diri, ia justru mampu menciptakan nyanyiannyanyian puitis yang mampu membekam mulut zaman, membuat setiap pendengarnya tersihir, memaksa sejarah untuk selalu bertepuk tangan saat mendengarnya kembali. ${ }^{10}$

Sesuai ajaran Personality Plus menjelaskan bahwa setiap orang memiliki kuasa yang bisa dibangkitkan untuk dipergunakan agar menjadi pribadi yang berpengaruh, oleh karena itu seseorang yang diberdayakan tidak harus menjadi paling baik atau paling berhasil, tetapi yang harus dilakukan adalah melakukannya dengan benar. Orang yang secara mental siap dan yang memiliki strategi psikologislah yang akan meraih kemenangan. ${ }^{11}$

Dalam bukunya John P. Kotler, Leading Change: Menjadi pionir Perubahan, ia mengemukakan bahwa terdapat kesalahan-kesalahan yang perlu dirubah pada diri seseorang dan organiasasi yakni :

1. Membiarkan adanya rasa puas diri yang terlalu berlebihan.

2. Gagal menciptakan pengarah yang kuat.

3. Meremekan kekuatan visi.

4. Pengkomunikasian Visi yang buruk.

5. Membiarkan hambatan-hambatan yang menghalangi visi.

6. Gagal menciptakan keuntungan jangka pendek.

7. Terlalu cepat menyatakan keberhasilan.

8. Lalai menanamkan perubahan yang kokoh.

\footnotetext{
${ }^{10}$ Aidh Al-Qarni, Laa Tahzan : Jangan Bersedih (Jakarta: Qisthi Press, 2004). Hlm. 20.

${ }^{11}$ Dave. J Lieberman \& Estelle Laurence, Personality Plus: Menjadi Pribadi yang Berpengaruh dan Disukai Banyak Teman (Yogyakarta: BACA! Baca buku buku baik, 2006), hlm. Back Cover.
} 
Dari kedelapan kesalahan tersebut timbulah konsekwensi-konsekwensi yang mengiringinya yaitu:

1. Strategi-strategi baru tidak diimplementasikan dengan baik.

2. Akuisisi tidak mencapai sinergi yang diharapkan.

3. Rekayasa ulang membutuhkan waktu yang terlalu lama dan biayaya yang banyak.

4. Perampingan tidak berhasil memotong biaya.

5. Program-program berkualitas tidak memberikan hasil yang sesuai dengan harapan.

Oleh karena itu untuk menciptakan sebuah perubahan dalam memberdayakan khususnya SDM itu sendiri perlu solusi yaitu:

1. Menetapkan makna urgensi dengan:

a. Melakukan penelitian pasar dan realitas kompetisi.

b. Mengidentifikasi dan membicarakan krisis, kemungkinan krisis, atau peluang-peluang besar.

2. Membentuk kualisi pengarah dengan:

a. Membentuk kelompok yang mempunyai cukup kekuatan untuk memimpin perubahan.

b. Membuat kelompok tersebut bekerja sama menjadi sebuah tim.

3. Mengembangkan Visi dan Strategi dengan:

a. Menciptakan visi untuk membantu menentukan arah dari usaha-usaha perubahan.

b. Mengembangkan strategi-strategi untuk mencapai visi.

4. Mengkomunikasikan visi perubahan dengan:

a. Menggunakan setiap sarana yang tepat untuk terus menerus mengkomunikasikan visi dan strategi baru.

b. Membuat kualisi pengarah sebagai contoh perilaku yang diharapkan dari para anggota.

5. Memberdayakan banyak orang untuk melakukan tindakan dengan:

a. Mengatasi semua hambatan.

b. Mengganti system atau struktur yang menghambat visi perubahan.

6. Menghasilkan keuntungan jangka pendek dengan: 
a. Merencanakan untuk meningkatkan kinerja yang jelas atau keuntungan secara nyata.

b. Menciptakan keuntungan-keuntunan tersebut.

c. Secara terbuka mengakui dan mengharai orang-orang yang memungkinkan keuntungan tersebut diperoleh.

7. Mengkonsolidasikan pencapaian-pencapaian dan menghasilkan lebih banyak perubahan dengan:

a. Menggunakan kredibilitas yang semakain meningkat untuk mengganti semua system, struktur, dan kebijakan yang tidak cocok satu sama lain dan tidak sesuai dengan visi transformasi.

b. Merekrut, mempromosikan, dan mengembangkan orang yang bisa mengimplementasikan visi perubahan.

c. Memperkuat kembali proses tersebut dengan proyek-proyek, tema dan pelaku-pelaku perubahan baru.

8. Mencanangkan pendekatan-pendekatan baru ke dalam kultur dengan :

a. Menciptakan kinerja yang lebih baik melalui perilaku yang berorientasi pada konsumen dan produktifitas, kepemimpinan yang lebih baik, dan manajemen yang lebih efektif.

b. Mengartikulasikan hubungan-hubungan antara perilaku-perilaku baru dan sukses organisasi.

c. Mengembangkan sarana untuk memastikan pengembangan kepemimpinan dan suksesi. ${ }^{12}$

Norman Vincent Peale dalam bukunynya "Sukses Luar Biasa dari Berfikir Positif" mengemukakan bahwa untuk dapat meraih kesuksesan setidaknya manusia terlebih dahulu memprakondisikan otak sehingga nantinya bisa meramalkan kegagalan dan keberhasilan. Ia juga menjelaskan bahwa kesuksesan seseorang mempunyai cirri-ciri yaitu terkontrol, terorganisasi, bukan menjadi bagian dari permasalahan tetapi bagian dari solusinya. ${ }^{13}$

\section{E. Pengembangan SDM Melalui Pendidikan}

\footnotetext{
${ }^{12}$ John P. Kotler, Leading Change: Menjadi pionir Perubahan (Jakarta: Gramedia, 1997), hlm. 20 \& 26.

${ }^{13}$ Norman Vincent Peale, Sukses Luar Biasa dari Berfikir Positif (Yogyakarta: BACA! Baca BukuBuku Baik, 2006).
} 
Pengembangan SDM merupakan suatu istilah yang digunakan untuk menggambarkan suatu pendekatan bersifat terintegrasi dan holistik dalam mengubah prilaku orang-orang yang terlibat alam suatu proses pekerjaan, dengan menggunakan serangkaian teknik dan strategi belajar yang relevan. Konsep ini mengandung makna adanya berbagai unsur kegiatan selama terjadinya proses mengubah prilaku, yaitu adanya unsur pendidikan, adanya unsur belajar, dan perkembangan. Unsur pendidikan dimaksudkan untuk menentukan teknik dan strategi yang relevan untuk mengubah prilaku. Unsur belajar dimaksudkan untuk menggambarkan proses terjadinya interaksi antara individu dengan lingkungan, termasuk dengan pendidik. Adapun unsur perkembangan dimaksudkan sebagai proses gradual dalam perubahan dari suatu keadaan, misalnya dari keadaan tidak dimilikinya kompetensi menjadi keadaan memiliki kompetensi, yang terjadi dalam jangka waktu tertentu.

Pengembangan SDM yang membawa misi sebagaimana disebutkan di atas difokuskan pada peningkatan ketahanan dan kompetensi setiap individu yang terlibat atau akan terlibat dalam proses pembangunan. Peningkatan ketahanan dan kompetensi ini di antaranya dilaksanakan melalui pendidikan. Bila dikaitkan dengan pengembangan SDM dalam rangka meningkatkan kemampuan menyesuaikan diri, pendidikan juga merupakan upaya meningkatkan derajat kompetensi dengan tujuan agar pesertanya adaptable terhadap berbagai perubahan dan tantangan yang dihadapi. Selain itu, pendidikan yang diselenggarakan seharusnya juga memberi bekal-bekal kemampuan dan keterampilan untuk melakukan suatu jenis pekerjaan tertentu yang dibutuhkan agar dapat berpartisipasi dalam pembangunan (Boediono, 1992). Program semacam ini harus dilaksanakan dengan disesuaikan dengan keperluan dan usaha yang mengarah kepada antisipasi berbagai perubahan yang terjadi, baik di masa kini maupun yang yang akan datang.

Sebagaimana dijelaskan di atas, pembangunan pada dasarnya merupakan suatu proses melakukan perubahan, dalam rangka perbaikan, untuk meningkatkan kesejahteraan rakyat dan kualitas sumber daya manusia (SDM). Kesejahteraan terkait dengan terpenuhinya kebutuhan dasar hidup rakyat, baik material maupun mental dan spiritual. Adapun kualitas SDM terkait dengan derajat kemampuan, termasuk kreatifitas, dan moralitas pelaku-pelaku pembangunan. Atas dasar ini, proses perubahan yang diupayakan melalui pembangunan seharusnya menjangkau perbaikan semua sektor secara menyeluruh dan berimbang, pada satu sisi, dan pada sisi lain merupakan upaya meningkatkan kualitas SDM. 
Perbaikan pemenuhan kebutuhan dasar rakyat adalah fokus dari pembangunan sektor ekonomi, dengan tujuan meningkatkan pemenuhan kebutuhan yang bersifat fisik dan material, baik kebutuhan primer, sekunder, tertier maupun kuarter. Pemenuhan kebutuhan ini seharusnya seimbang dengan pemenuhan kebutuhan mental dan spiritual. Bebas dari rasa takut, adanya rasa aman, dihargai harkat dan martabatnya, dilidungi kebebasan dan hak-haknya, serta tersedianya kesempatan yang sama untuk mewujudkan cita-cita dan potensi diri adalah bentuk-bentuk kebutuhan mental yang seharusnya diperbaiki kondisinya melalui pembangunan. Adapun pemenuhan kebutuhan spiritual terkait dengan kebebasan dan ketersediaan prasarana, sarana dan kesempatan untuk mempelajari, mendalami dan menjalankan ajaran agama yang dianut, sehingga komunikasi dengan Sang Pencipta dapat terpelihara. ${ }^{14}$

Bila dikaitkan dengan pengembangan SDM dalam rangka meningkatkan kemampuan menyesuaikan diri, pendidikan juga merupakan upaya meningkatkan derajat kompetensi dengan tujuan agar pesertanya adaptable terhadap berbagai perubahan dan tantangan yang dihadapi. Selain itu, pendidikan yang diselenggarakan seharusnya juga memberi bekal-bekal kemampuan dan keterampilan untuk melakukan suatu jenis pekerjaan tertentu yang dibutuhkan agar dapat berpartisipasi dalam pembangunan.Karena SDM berkualitas adalah keluaran sistem pendidikan, proses pendidikan harusnya menjadikan kreatifitas, penguasaan dan kemampuan mengembangkan IPTEKS, serta moralitas sebagai acuan dasar. Agar pendidikan menghasilkan keluaran, yaitu SDM yang berkualitas, kurikulum seharusnya tidak terlalu sarat dengan mata-mata ajaran. Isi kurikulum perlu dibatasi pada kompetensi atau persyaratan minimal yang harus dimiliki seseorang untuk diakui telah menyelesaikan suatu jenjang pendidikan tertentu. Kompetensi minimal ini dikaitkan dengan dua kepentingan, yaitu untuk menjalani hidup dimasyarakat dan untuk melanjutkan pendidikan pada jenjang berikutnya. Dengan demikian, tersedia waktu yang memadai untuk penerapan model-model pembelajaran memungkinkan siswa menguasai dan mampu mengembangkan isi mata ajaran (berkait dengan IPTEKS), dan mengembangkan kreatifitas dan moralitas. ${ }^{15}$

Rendahnya daya saing dan angka HDI Indonesia disebabkan oleh banyak faktor antara lain kondisi perekonomian yang menyebabkan rendahnya tingkat penghidupan masyarakat secara ekonomi. Hal ini jelas mempengaruhi kemampuan finansial mereka

\footnotetext{
${ }^{14}$ Abdullah NS., "Pemberdayaan Budaya" Mimbar Pendidikan, No. 3/XVII/1998, hlm. 30.

${ }^{15}$ Mohammad Ali, Pendidikan dalam Perspektif .... , hlm. 26.
} 
untuk membiayai pendidikan anak-anak mereka bahkan anak-anak usia sekolah terpaksa meninggalkan bangku sekolah demi membantu orang tua mencari nafkah. Investasi di bidang SDM ini penting dan dapat dicapai dengan program pengembangan yang tepat dan berkelanjutan, komitmen kuat dan keberpihakan pemerintah sebagai regulator dan lokomotif penggerak utama dalam pengembangan kualitas SDM. ${ }^{16}$

Generasi yang berkualitas yang akan disiapkan untuk menyongsong dan menjadi pelaku pembangunan pada era globalisasi dituntut untuk meningkatkan kualitas keberagamaannya (dalam memahami, menghayati, dan mengamalkan agamayang tetap bertumpu pada iman dan aqidah). Dengan kata lain masyarakat maju Indonesia menuntut kemajuan kualitas hasil pendidikan Islam. A. R. Saleh menyatakan bahwa modernisasi bagi bangsa Indonesia adalah penerapan ilmu pengetahuan dalam aktivitas pendidikan Islam secara sistematis dan berlanjut. Tujuan pendidikan nasional termasuk tujuan pendidikan agama adalah mendidik anak untuk menjadi anak manusia berkualitas dalam ukuran dunia dan akhirat. ${ }^{17}$

\section{F. Pengembangan SDM dalam Pendidikan Islam}

1. Hakikat pengembangan SDM dalam pendidikan islam

Era globalisasi dewasa ini dan masa yang akan datang sangat mempengaruhi perkembangan sosial budaya masyarakat muslim Indonesia termasuk pendidikan Islam khususnya. Pendidikan Islam secara langsung akan terkena pengaruhnya, oleh karena itu Pendidikan Islam harus bisa survive agar berjaya dalam kompetisi abad 21. Globalisai tidak sekedar memberi tantangan tetapi memberikan peluang-peluang penting termasuk bidang ekonomi yang member pengaruh positif bagi kehidupan sosial ekonomi bangsa yang pada gilirannya akan mendorong peningkatan intensitas kehidupan agama.

Semuanya akan terwujud dengan adanya pengembangan dan penguasaan sains dan teknologi yang tidak lepas dari landasan moral dan etis. Disinilah terletak keharusan dan tanggung jawab kemanusiaan bagi Indonesia untuk berusaha

\footnotetext{
${ }^{16}$ Santi Aprilianti, Pengembangan SDM dalam Pendidikan ...2009.

${ }^{17}$ Shaleh, A. R., Pendidikan Agama dan Keagamaan : Visi, Misi dan Aksi,(Jakarta : Gemawindu Pancaperkasa, 2000), hlm. 203-205.
} 
mengembangkan sains dan teknologi yang bermoral dan etis. Indonesia sudah mempunyai modal dasar yaitu memiliki umat yang agamis dan taat dalam menjalankan agamanya.Untuk itu tugas pendidikan Islam perlu berperan lebih dan proaktif dalam menciptakan anak didik yang siap melangkah ke arah tersebut. ${ }^{18}$

Yang menjadi dilema sekarang ini adalah pengentasan kemiskinan dipandang terlalu menekan pada masalah material bukan menjadikan SDM lebih berkualitas. Yang menjadi tekanan paling penting adalah pengentasan kemiskinan dengan upaya peningkatan kualitas SDM melalui pendidikan. Hal semacam ini sudah diajarkan oleh Nabi Muhammad saw dengan cara melaksanakan peningkatan SDM secara mandiri lewat bisnis perdagangan untuk menopang perekonomian keluarganya disamping Nabi sebagai pendidik umat untuk mengajarkan ilmu agama secara mantap dan konsisten dengan bekal kepribadian yang terpuji dan pandai mencari hikmah sebagai kunci sukses sebagai seorang pendidik sehingga medapatkan keseimbangan dunia dan akhirat.

2. Fungsi pendidikan Islam dalam pengembangan SDM

Menurut fungsinya pendidikan Islam secara jelas berperan penting dalam meningkatkan kualitas SDM yang berkualitas tinggi baik dalam penguasaan terhadap ilmu pengetahuan dan teknologi maupun dalam hal karakter, sikap moral dan penghayatan dan pengamalan ajaran agama. Secara singkat pendidikan Islam secara ideal membina dan menyiapkan anak didik yang berilmu, berteknologi, berketerampilan tinggi dan sekaligus beriman dan beramal saleh.

Konferensi Internasinal pertama tentang pendidikan Islam di Makah tahun 1977 merumuskan tujuan Pendidikan Islam yakni untuk mencapai pertumbuhan kepribadian manusia yang menyeluruh secara seimbang melalui latihan jiwa, intelek, diri manusia yang rasional, perasaan dan indra. Karena itu pendidikan harus mencakup pertumbuhan manusia dalam segala aspeknya : spiritual, intelektual, imajinatif, fisik, ilmiah, bahasa baik secara individual maupun secara kolektif, dan mendorong semua aspek ini ke arah kebaikan dan mencapai kesempurnaan. Tujuan terakhir pendidikan Muslim terletak pada perwujudan ketundukan yang sempurna kepada Allah baik secara pribadi, komunitas maupun seluruh umat manusia.

\footnotetext{
${ }^{18}$ Azyumardi Azra, Pendidikan Islam “Tradisi dan Modernisasi Menuju Milenium Baru” (Jakarta : Logod Wacana Ilmu, 1999), hlm. 43-47.
} 
M. Natsir menyatakan bahwa ideologi pendidikan Islam menyatakan, "Yang dinamakan pendidikan Islam ialah suatu pimpinan jasmani dan rohani menuju kesempurnaan dan kelengkapan arti kemanusiaan dengan arti sesungguhnya. Manusia diciptakan oleh Allah SWT dalam rangka menjadi khalifah dimuka bumi, hal ini banyak dicantumkan dalam al-Qur'an dengan maksud agar manusia dengan kekuatan yang dimilikinya mampu membangun dan memakmurkan bumi serta melestarikannya. Untuk mencapai derajat khalifah di muka bumi ini diperlukan proses yang panjang, dalam Islam upaya tersebut ditandai dengan pendidikan yang dimulai sejak buaian sampai ke liang lahat.

Dalam kerangka perwujudan fungsi idealnya untuk peningkatan kualitas SDM tersebut, system pendidikan Islamharus senantiasa mengorientasikan diri kepada menjawab kebutuhan dan tantangan yang muncul dalam masyarakat kita sebagai konsekwensi logis dari perubahan. Indonesia telah masuk ke dalam barisan negaranegara industri baru yang mengharuskan meningkatkan pembangunannya dengan menyiapkan kualitas SDM yang seutunya lewat pendidikan yang menyatu dalam satu system pendidikan nasional yang bermutu tinggi yang siap bertarung dikancah internasional tanpa harus menyingkirkan agama seperti negara-negara sekuler di Eropa. Iptek memang perlu tetapi jangan sampai lupa akan Imtak yang akan mengantarkan manusia Indonesia yang kamil. ${ }^{19}$ Usaha untuk meningkatkan mutu SDM tidak dapat dilakukan semata-mata pada langkah-langkah yang dilakukan di bidang formal tetapi dapat ditambah dengan pelatihan-pelatihan jangka pendek melalui pelatihan-pelatihan lewat pendidikan non-formal. ${ }^{20}$

Agar pendidikan Islam tidak menjadi alternatif sampingan atau boleh dikatakan sebagai kelompok residu maka perlu pembuktian dengan melahirkan SDM yang mampu berkompetisi. Tentunya hal ini menjadi bagian dari pendidikan Islam yang bertugas mencetak kualitas SDM yang tak kalah dengan pendidikan umum. ${ }^{21}$ Untuk menjawab tantangan dan menghadapi tuntutan pembangunan pada era globalisasi diisyaratkan dan diperlukan kesiapan dan lahirnya masyarakat modern Indonesia. Aspek yang spektakuler dalam masyarakat modern adalah penggantian teknik produksi dari cara tradisional ke cara modern yang ditampung dalam

\footnotetext{
${ }^{19}$ Ibid., hlm. 53-57.

${ }^{20}$ Mochtar Buchori, Transformasi Pendidikan,(Jakarta : Midas Surya Grafindo, 1995), hlm 6.

${ }^{21}$ Muslih Usa dan Aden Wijdan, Pendidikan Islam dalam Peradaban Industrial,(Yogyakarta : Aditya Media, 1997), hlm. 192-193.
} 
pengertian revolusi industri. Secara keliru sering dikira bahwa modernisasi hanyalah aspek industri dan teknologi saja. Padahal secara umum dapat dikatakan bahwa modernisasi masyarakat adalah penerapan pengetahuan ilmiah yang ada kepada semua aktivitas dan semua aspek hidup masyarakat. ${ }^{22}$

\section{G. Pengembangan Kualitas SDM Madrasah Berwawasan Global}

Ketahanan suatu masyarakat ditentukan oleh tiga unsur ialah sumber daya alamnya, sumberdaya manusianya yang berkualitas, dan sumber daya kebudayaan dan kesejarahannya. ${ }^{23}$ Kiranya, beberapa karakteristik itulah yang perlu dimiliki dan dikembangkan di dalam pengembangan sumber daya manusia di lembaga pendidikan Islamyang dalam hal ini dapat diwakili oleh pesantren, madrasah dan sekolah Islam.

Madrasah dalam tujuannya berupaya mengintegrasikan ilmu agama dan umum. Menyeimbangkan keduanya untuk menggapai kebahagiaan dunia dan akhirat. Hal ini sesuai dengan Q.S. (Al-Qasas (28): 77: "Dan carilah pada apa yang Telah dianugerahkan Allah kepadamu (kebahagiaan) negeri akhirat, dan janganlah kamu melupakan bahagianmu dari (kenikmatan) duniawi dan berbuat baiklah (kepada orang lain) sebagaimana Allah Telah berbuat baik, kepadamu, dan janganlah kamu berbuat kerusakan di (muka) bumi. Sesungguhnya Allah tidak menyukai orang-orang yang berbuat kerusakan."(Q.S. Al-Qashas: 77).

Ada beberapa aspek yang perlu dikembangkan dalam lingkup lembaga pendidikan Islam pada umumnya, dan Madrasah pada khususnya untuk menumbuhkan kualitas SDM yang berwawasan global paling tidak harus asanya pengelolaan yang baik aspek-aspek dibawah ini, yaitu:

1. Aspek pendidikan (pedagogis). Sebagai lembaga yang bergerak dalam dunia pendidikan, lembaga pendidikan Islam berperan penting dalam peningkatan SDM yang berkualitas dan melahirkan kader-kader pemimpin bangsa dan agama yang memiliki wawasan keislaman dan nasionalisme yang tinggi serta mempunyai pandangan yang luas tentang dunia luar. Hal ini didasarkan pada pandangan bahwa reformasi dan pembaharuan dalam Islam haurus dimulai dari pendidikan. ${ }^{24}$

\footnotetext{
${ }^{22}$ Djaafar, T. Z., Pendidikan Non Formal dan Peningkatan Sumber Daya Manusia Dalam Pembangunan, ( Padang: FIP UNP, 2001), hlm. 23.

${ }^{23}$ H.A.R. Tilaar, Membenahi Pendidikan Nasional, (Jakarta: PT Rineka Cipta. 2002). hlm. 60.

${ }^{24}$ A. Fatah Yasin, "Masjid: Lembaga Alternatif Pengembangan Pendidikan Islam", Jurnal el Hikmah
} Vol. 1 No. 1, 2003. 
2. Aspek Moral-Spiritual. Pendidikan Islam bertujuan membina peserta didik menjadi seseorang yang mencapai derajat ulul albab yakni intelektual muslim yang tangguh, yang tidak hanya memiliki ketajaman analisis obyektif, tetapi juga subyektif. ${ }^{25}$ Lembaga pendidikan Islam berupaya memberikan penguatan dan dasar pemahaman keagaamaan secara baik. Mengajarkan nilai-nilai kejujuran, kerendahan hati, kesederhanaan dan nilai-nilai keluruhan kemanusiaan. Nilai keluhuran itulah yang mengantarkan peserta didik mendapat penilaian yang baik di sisi masyarakat dan di mata Tuhan-Nya.

3. Aspek sosio-kultural. Tidak dapat dipungkiri lembaga pendidikan Islam memberikan pengaruh yang signifikan terhadap corak karekter masyarakat. Merespons persoalan-persoalan masyarakat seperti memelihara tali persaudaraan, menciptakan kehidupan yang sehat dan sebagainya. Lembaga pendidikan dalam aspek ini memberikan penanaman akan pentingnya makna-makna etis dalam dialog keagamaan, khususnya istitusi pendidikan Islam. ${ }^{26}$

4. Aspek Sistem pendidikan. Sistem pendidikan di lembaga pendidikan Islam yang tumbuh dan berkembang dapat berbentuk isolatif tradisional, serta bercorak sintesis dengan berbagai variasi pola pendidikannya.

5. Aspek SARANA dan prasarana. Madrasah kita masih belum mampu menyediakan secara khusus, karena konsekwensinya adalah sumberdana masyarakat yang sangat terbatas, dan juga aspek-aspek lain. ${ }^{27}$

\section{H. Kesimpulan}

Pengembangan Sumber Daya Manusia adalah perencanaan, pengorganisasian, pengarahan, pengembangan, pemberian kompensasi, pengintegrasian, pemeliharaan, dan pelepasan sumber daya manusia agar tercapai tujuan organisasi dan masyarakat. Tujuan dari pengernbangan sumber daya manusia tersebut adalah untuk meningkatkan pengetahuan, keterampilan, dan komitmen tenaga kerja (pendidik dan tenaga kependidikan), sehingga visi dan misi lembaga dapat dicapai dengan efektif dan efisien. Masa depan dan kelestarian suatu organisasi tergantung pada pengetahuan, keterampilan dan kompetensi SDM, serta sinergi antara SDM sebagai penggerak

\footnotetext{
${ }^{25}$ H. Muhaimin, "Penyiapan Ulul Albab Alternatif Pendidikan Islam Masa Depan”Jurnal el Hikmah, Vol.1 No. 1 Tahun 2003. Hlm. 5.

${ }^{26}$ Muhammad In'am Esha, “Dialog Keagamaan dan Implikasinya dalam Pendidikan”Jurnal El Hikmah, Volume III No. 2 Tahun 2006. Hlm. 179.

${ }^{27}$ H. Muhaimin, "Perbincangan tentang Pendidikan Islam di Indonesia"Jurnal Ulul Albab UIN Malang,Vol. 3 No. 2 Tahun 2002. Hlm. 7 .
} 
organisasi dan pengelolaan yang efektif sumber daya lainnya yang ada dalam organisasi tersebut.

Investasi pengembangan SDM merupakan program jangka panjang yang di dalamnya terdapat program jangka menengahyang harus sedini mungkin diformulasikan perencanaanya dan diimplementasikan. Investasi ini harus menunjang perkembangan ekonomi dengan visi membangun suatu masyarakat madani yang makmur dan berkeadilan. Dalam hal ini ada tiga hal yang perlu dilakukan yaitu sumber daya sejarah dan budaya, kualitas sumber daya manusia, pemberdayaan rakyat.

Selain berkaitan dengan sistem masyarakat secara umum, kualitas SDM mempunyai keterkaitan erat dengan kualitas pendidikan sekolah. Karena SDM berkualitas adalah keluaran sistem pendidikan, proses pendidikan harusnya menjadikan kreatifitas, penguasaan dan kemampuan mengembangkan IPTEKS, serta moralitas sebagai acuan dasar. Agar pendidikan menghasilkan keluaran, yaitu SDM yang berkualitas, kurikulum seharusnya tidak terlalu sarat dengan mata-mata ajaran.

Madrasah dalam tujuannya berupaya mengintegrasikan ilmu agama dan umum. Menyeimbangkan keduanya untuk menggapai kebahagiaan dunia dan akhirat. Ada beberapa aspek yang perlu dikembangkan dalam lingkup lembaga pendidikan Islam pada umumnya, dan Madrasah pada khususnya untuk menumbuhkan kualitas SDM yang berwawasan global paling tidak harus asanya pengelolaan yang baik aspek-aspek dibawah ini, yaitu aspek pendidikan (pedagogis), aspek Moral-Spiritual, aspek sosio-kultural, aspek Sistem pendidikan, aspek sarana dan prasarana.

\section{DAFTAR PUSTAKA}

Abdullah NS., "Pemberdayaan Budaya", Mimbar Pendidikan,No. 3/XVII/ 1998.

Aly, H. N. dan Munzier, H., Watak Pendidikan Islam, Jakarta : Friska Agung Insani, 2001. 
Aidh Al-Qarni, Laa Tahzan : Jangan Bersedih, Jakarta: Qisthi Press, 2004.

A. Fatah Yasin, "Masjid: Lembaga Alternatif Pengembangan Pendidikan Islam" , Jurnal el Hikmah Vol. 1 No. 1, 2003.

Azyumardi Azra, Pendidikan Islam "Tradisi dan Modernisasi Menuju Milenium Baru" Jakarta : Logod Wacana Ilmu, 1999.

Mohammad Ali, Pendidikan dalam Perspektif Pengembangan SDM, Bandung: FIP, IKIP, 1999.

Carles Newton, Nothing to Something: Menyingkap rahasia Sukses, Yogyakarta: BACA! Baca buku buku baik, 2007.

Dale Carnagie, Petunjuk Menikmati Hidup dan Pekerjaan Anda, Jakarta: Gramedia, 2004.

Dave. J Lieberman \& Estelle Laurence, Personality Plus: Menjadi Pribadi yang Berpengaruh dan Disukai Banyak Teman, Yogyakarta: BACA! Baca buku buku baik, 2006.

Djaafar, T. Z.. Pendidikan Non Formal Dan Peningkatan Sumber Daya Manusia Dalam Pembangunan. Padang, Padang: FIP UNP, 2001.

Hartoyo, "Pengembangan Sumber Daya Manusia (SDM) Pendidikan", Pelatihan Peningkatan Kemampuan Tenaga Perencana Akademik Bagi Dosen STTA Yogyakarta. 1 Agustus 2008 Di P3AI UNY.

H.A.R. Tilaar, Membenahi Pendidikan nasional, Jakarta : Rineka Cipta, 2002.

H. Muhaimin, "Penyiapan Ulul Albab Alternatif Pendidikan Islam Masa Depan" Jurnal el Hikmah, Vol.1 No. 1 Tahun 2003.

, "Perbincangan tentang Pendidikan Islam di Indonesia" Jurnal Ulul Albab UIN Malang, Vol. 3 No. 2 Tahun 2002.

John P. Kotler, Leading Change: Menjadi Pionir Perubahan, Jakarta: Gramedia, 1997.

Moh. Ali, "Pendidikan dan Perspektif”Mimbar Pendidikan, No. 3/XVIII/1999.

Mochtar Buchori, Transformasi Pendidikan, Jakarta : Midas Surya Grafindo, 1995.

Muslih Usa dan Aden Wijdan, Pendidikan Islam dalam Peradaban Industrial, Yogyakarta : Aditya Media, 1997.

Muhammad In'am Esha, "Dialog Keagamaan dan Implikasinya dalam Pendidikan” Jurnal El Hikmah, Volume III No. 2 Tahun 2006.

Norman Vincent Peale, Sukses Luar Biasa dari Berfikir Positif, Yogyakarta: BACA! Baca buku buku baik, 2006. 
Santi Aprilianti, Pengembangan SDM dalam Pendidikan ...2009.

Shaleh, A. R., Pendidikan Agama dan Keagamaan : Visi, Misi dan Aksi, Jakarta : Gemawindu Pancaperkasa, 2000.

Simanjuntak, P., Pengantar Ekonomi Sumber Daya Manusia, Jakarta: Lembaga Penerbit Fakultas Ekonomi, Universitas Indonesia, 1985.

Yasnimar Ilyas dan Amin Zuhairi, "Pengembangan Sistem Penilaian Kinerja Sumber Daya Manusia Pada Institusi Pendidikan Tinggi Jarak Jauh", Jurnal Pendidikan Terbuka dan Jarak Jauh, Vol. 5, No.1, Maret 2004. 